\title{
EVALUASI PENGGUNAAN OBAT ANTI HIPERTENSI PADA PASIEN GAGAL GINJAL KRONIK YANG MENJALANI HEMODIALISIS
}

\section{EVALUATION OF DRUG USE IN ANTI HYPERTENSION PATIENTS WHO CHRONIC RENAL FAILURE UNDERGO HEMODIALYSIS}

\author{
Woro Supadmi \\ Fakultas Farmasi Universitas Ahmad Dahlan \\ Jl. Prof.Dr. Soepomo, Telp. (0274) 379418 \\ Yogyakarta
}

\section{Abstrak}

Intervensi dialisis memunculkan berbagai komplikasi pada pasien diantaranya hipertensi intradialitik sebagai akibat adanya perubahan hemodinamik. Fenomena paradoks tersebut diantaranya disebabkan aktivasi berbagai vasopresor endogen akibat adanya perubahan status volume maupun faktor terdialisisnya obat antihipertensi. Penelitian ini bertujuan untuk mengetahui pola penggunaan obat anti hipertensi, mengevaluasi rasionalitas dan efek samping obat anti hipertensi berdasarkan literarur. Penelitian ini dilakukan dengan observasi keadaan pasien berdasarkan rekam medis pasien untuk melihat data obat, data laboratorium pasien dan kondisi pasien. Penelitian retrospektif pada pasien hemodialisis di rumah sakit PKU Muhammadiyah Yogyakarta periode tahun 2009 - 2010. Pasien sesuai dengan kriteria inklusi, yaitu meggunakan obat anti hipertensi dan data rekam medik lengkap. Evaluasi rasionalitas penggunaan obat anti hipertensi meliputi tepat dosis, tepat pasien dan efek samping berdasarkan Drug Informasi Hand Book 2005, Handbook of Clinical Drug Data 2002 dan literatur yang lain. Penelitian diperoleh 60 pasien yang sesuai dengan kriteria inklusi. Berdasarkan hasil penelitian pola penggunaan obat anti hipertensi pada pasien hemodialisis adalah captoril, furosemida, nifedipin, lisinopril, amlodipin, valsatran dan clonidin. Evaluasi rasionalitas penggunaan obat tidak tepat dosis penggunaan captopril 11 pasien dari 34 pasien dan furosemid 18 pasien dari 52 pasien, tidak tepat pasien adalah penggunaan captopril 9 pasien dari 34 pasien. Efek samping yang terjadi pada pasien akibat penggunaan furosemida adalah hipokalemia 40 pasien, batuk karena captopril adalah 13 pasien, efek samping nifedipin batuk dan gangguan gastrointestinal 11 pasien, batuk karena lisinopril 5 pasien. Penggunaan obat anti hipertensi pada pasien hemodialisa Di RSU PKU Muhammdiyah Yogyakarta sudah rasional.

Kata kunci : Evaluasi terapi, anti hipertensi, pasien hemodialisa 


\section{Abstract}

The intervention led to various complications in dialysis patients include hypertension intradialitik as a result of hemodynamic changes. The phenomenon of the paradox of which caused activation of endogenous vasopresor due to changes in volume status and antihypertensive medication terdialisisnya factor. This study aims to determine patterns of use of antihypertensive drugs, evaluating the rationality and side effects of antihypertensive drugs based on literarur. This study was performed with the patient's condition based on the observation of patients to see medical records drug data, laboratory data of patients and patient's condition.Retrospective study of hemodialysis patients in the hospital PKU Muhammadiyah Yogyakarta year period from 2009 to 2010.Patients according to inclusion criteria, anti-hypertensive drug receipts and complete medical record data.Evaluation of rationality involves the use of antihypertensive drugs right dose, right patient and side effects based on the Drug Information Hand Book 2005, Handbook of Clinical Drug Data, 2002. The study found 60 patients who fit the inclusion criteria.Based on the research patterns of use of antihypertensive drugs in patients with hemodialysis is captoril, furosemide, nifedipine, lisinopril, amlodipine, valsatran and clonidin. Evaluation rationality inappropriate use of drugs dose use of captopril 11 patients of 34 patients and furosemide 18 patients from 52 patients, inappropriate use of captopril patients was 9 patients of 34 patients. Side effects that occur in patients with hypokalemia due to the use of furosemide is 40 patients, cough due to captopril was 13 patients, side effects of nifedipine gastrointestinal disorders cough and 11 patients, 5 patients cough lisinopril.Conclusion:he use of antihypertensive medications in hemodialysis patientsat RSU PKU Muhammadiyah Yogyakarta is rational.

Keywords : Evaluation of therapy, antihypertension, hemodialysis patients

\section{PENDAHULUAN}

Gagal Ginjal Kronik (GGK) merupakan masalah kesehatan dunia dengan peningkatan insiden, prevalensi serta tingkat morbiditas. Penyakit gagal ginjal kronik memerlukan biaya perawatan yang mahal dengan hasil perawatan yang buruk (National Kidney Foundation, 2005). Angka kematian akibat gagal ginjal kronik atau end stage renal disease dengan dialisis terus meningkat di banyak negara termasuk negara berkembang seperti Indonesia, pada tahun 2003 terdapat 210 pasien dialisis meninggal dari 1000 pasien (Strong et al,2005).

Pasien penyakit gagal ginjal kronik tahap akhir diindikasikan untuk memperoleh terapi renal replacement therapy, yaitu dialisis. Dialisis yang dimaksud baik dialisis peritonial maupun hemodialisis (Decker et al, 2007 ; Shargel dan Yu, 1985). Dialisis merupakan suatu proses buatan di mana akumulasi obat atau metabolit-metabolit 
sisa dipindahkan melalui difusi dari tubuh ke dalam cairan dialisis. Intervensi dialisis memunculkan berbagai komplikasi pada pasien diantaranya hipertensi intradialitik sebagai akibat adanya perubahan hemodinamik (Zoccali dan Dunea, 2001 ; Chen et al, 2006). Hipertensi akibat komplikasi ini tentunya akan semakin mempercepat perkembangan penyakit serta menambah laju mortalitas pasien. Menurut European Society of HypertensionEuropean Society of Cardiology (2003) dan 7th Joint National Committee of Hypertension (2004), target tekanan darah pada pasien hipertensi dengan penyakit ginjal sebagai faktor penyulit disarankan $<130 / 80 \mathrm{mmHg}$. Pencapaian target ini diperberat dengan adanya hipertensi akibat komplikasi hemodialisis. Namun, baik definisi maupun mekanisme patologis hipertensi intradialitik belum disepakati oleh para ahli (Chen et al, 2006). Hal ini menjadi tantangan berat yang menuntut untuk segera diungkap mengingat kondisi hipertensi yang tidak terkontrol merupakan faktor risiko terjadinya komplikasi kardiovaskular yang mempengaruhi morbiditas dan mortalitas pasien dengan hemodialisis kronis (Agarwal, 1999). Kondisi tersebut menjadi dasar pentingnya pemberian obat antihipertensi pada pasien dengan hemodialisis (National KidneyFoundation, 2005 ; Bishu, 2006).

Tatalaksana terapi pada pasien hipertensi yang menjalani hemodialisis memerlukan perhatian pada manajemen status cairan/volume ekstra vaskuler dan penyesuaian terapi antihipertensi (National Kidney Foundation, 2005). Penyesuaian terapi diperlukan karena adanya jenis obat antihipertensi yang terdialisis serta adanya abnormalitas respon tubuh terhadap hemodialisis. Kadar obat yang terdialisis mengakibatkan penurunan efektifitas obat atau under dose (Bochler et al, 1999 ; Chen et al, 2006) yang berakibat tidak terkontrolnya tekanan darah sehingga meningkatkan risiko penyakit jantung dan pembuluh (Agarwal,1999). Oleh karenanya, kadangkala pasien membutuhkankan adanya supplemental dose dari obat yang digunakan setelah dialisis untuk mempertahankan konsentrasi obat di dalam darah (Quan dan Aweeka, 2005; Bochler et al, 1999 ; Keller et al, 1999 ). Bahkan berkurangnya kadar obat di dalam darah dapat berakibat fatal pada pasien dengan kondisi kritis (Keller et al, 1999).

Insidensi gagal ginjal kronik di Yogyakarta diperkirakan sebesar 1000 orang tiap 1 juta penduduk atau seorang penderita tiap 1.000 penduduk. Rumah sakit yang melayani hemodialisa adalah RSUP Dr. Sardjito, RS PKU Muhammadiyah, RS Panti Rapih dan RS Bethesda. Gambaran pelaksanaan pelayanan hemodialisa bulanan di beberapa Rumah Sakit sampai bulan Agustus 2006 sebagai berikut RS Bethesda melayani 91 pasien dengan 636 kali cuci darah, RS PKU Muhammadiyah sebesar 244 pasien dengan 1.927 kali cuci darah dan RS Panti Rapih melayani sebesar 364 pasien dengan 2.412 kali cuci darah (Kompas, 5/8/2006).

Hipertensi umum terjadi dan sulit terkontrol dengan baik pada pasien dengan hemodialisis kronis (Rahman dan Griffin, 2004). Target tekanan darah yang dijadikan pedoman pada populasi ini sebagaimana yang dijadikan pedoman pada populasi umumnya. Antara $50 \%$ 
- 90\% pasien hemodialisis memiliki tekanan darah lebih dari 140/90 $\mathrm{mmHg}$. Terapi yang digunakan pada pasien dengan hemodialisis kronis memiliki tujuan utama untuk mencegah manifestasi progresifitas penyakit pada kardiovaskular (Hort dan Horl, 2002 ; Rahman dan Griffin, 2004) yang diakibatkan dari hipertensi tidak terkontrol. Agarwal (1999) menyebutkan bahwa penghentian obat sebelum dialisis yang dimaksudkan untuk menghindarkan pasien dari ancaman hipotensi intradialitik ironisnya akan berakibat berkembangnya hipertrofi ventrikel kiri yang akan menyebabkan terjadinya efek hipotensif akibat menurunnya compliance jantung. Risiko gangguan kardiovaskuler dicerminkan dengan hipertensi sistolik (ESH-ECH, 2003) sehingga terapi ditujukan untuk mengatasi hipertensi sistolik pra dialisis daripada sistolik pasca-dialisis (Hort dan Horl, 2002). Namun, menurut Salem (1999) rendahnya tekanan darah dikaitkan pada risiko terjadinya cerebro vascularaccident terutama pada populasi pasien lebih dari 60 tahun yang umumnya memiliki penyakit atherosclerosis. Idealnya tekanan darah pada populasi tersebut lebih dari160/90 mm Hg untuk mempertahankan perfusi yang cukup. Proses hemodialisis dan terapi anti- hipertensi dalam kasus hipertensi intradialitik seringkali berlawanan. Terapi yang diberikan berfungsi me- nurunkan tekanan darah sedangkan proses hemodialisis merangsang tubuh untuk terjadinya hipertensi. Proses hemodialisis yang meningkatkan kliren obat-obat tertentu berakibat meningkat- kan tekanan darah. Penurunan kadar antihipertensi selama proses dialisis dapat memicu terjadinya hipertensi intradialitik (Chen et al, 2006). Anti- hipertensi yang terdialisis adalah yang termetabolisme di ginjal, memiliki karakter kelarutan dalam air yang tinggi, ikatan protein yang rendah serta bobot molekul yang kecil (Johnson, 2008).

Melalui penelitian ini diharapkan dapat mengetahui pola penggunaan obat anti hipertensi pada pasien gagal ginjal kronik dengan hemodialisa, rasionalitas penggunaan obat anti hipertensi dan efek samping yang terjadi akibat penggunaan obat anti hipertensi pada pasien gagal ginjal kronik dengan hemodialisa di RSU PKU Muhammadiyah Yogyakarta.

\section{METODE PENELITIAN}

Penelitian ini merupakan penelitian deskriptif non eksperimental dengan pengumpulan data secara retropektif. Observasi dilakukan terhadap sejumlah subjek penelitian menurut keadaan yang ada dengan cara survei langsung. Sumber data penelitian adalah semua rekam medik pasien gagal ginjal kronik yang melakukan hemodialisa di bangsal Hemodralisa di RS PKU Muhammadyah Yogyakarta selama periode tahun 2009 - 2010. Kriteria inklusi pasien yang menunjukkan tekanan darah paska dialisis lebih dari atau sama dengan 150/90 mmHg pada pengukuran basal dan menjalani terapi hipertensi akibat karena peningkatan tekanan darah pada saat proses Hemodialisis (hipertensi intradialitik). Kriteria eksklusi pasien dengan kondisi critically ill yang membatasi dilakukannya intervensi penyesuian dosis maupun penambahan antihipertensi. 
Data pasien yang tercatat di dalam rekam medik pasien di bangsal hemodialisis Rumah Sakit PKU Muhammadyah Yogyakarta yang memuat identitas pasien, profil subyektif, obyektif, observasi tanda-tanda vital, penilaian dan tatalaksana terapi oleh dokter selama periode penelitian. Hasil penelitian dianalisis dengan metode deskriptif dengan mengevaluasi rasionalitas penggunaan obat anti hipertensi tepat dosis, tepat pasien dan efek samping obat berdasarkan literatur dengan menggunakan acuan referensi Drug Informasi Hand Book 2005, Handbook of Clinical Drug Data 2002 dan literatur yang lain.

\section{HASIL DAN PEMBAHASAN}

Hasil penelitian diperoleh 60 orang pasien yang melakukan hemodiasis dan sesuai dengan kriteria inklusi. Pada 60 orang pasien diberikan obat antihipertensi untuk penanganan kenaikkan tekanan darah pasien. Hemodialisis sebagai salah satu modalitas terapi penyakit ginjal kronis yang telah mencapai tahap akhir memicu terjadinya komplikasi hipertensi. Komplikasi hemodialisis-induced hypertension yang dikenal dengan hipertensi intradialitik. Penelitian ini dilakukan untuk mengevaluasi terapi antihipertensi yang dilakukan pada pasien penyakit ginjal kronis dengan hemodialisis.

\section{A. Karakteristik Pasien}

\section{Distribusi pasien berdasarkan jenis kelamin dan usia}

Jenis kelamin dan usia berdasarkan Price dan Wilson, 2002 berpengaruh terhadap kejadian penyakit glomerulonefritis yang merupakan salah satu faktor risiko gagal ginjal kronik. Distribusi pasien berdasarkan jenis kelamin dan usia pada tabel 1 .

Tabel 1. Distribusi pasien berdasarkan jenis kelamin dan usia

\begin{tabular}{|l|c|c|}
\hline $\begin{array}{c}\text { Karakteristik } \\
\text { pasien }\end{array}$ & Jumlah & Persentase \\
\hline $\begin{array}{l}\text { Jenis kelamin } \\
\text { 1. Laki-laki }\end{array}$ & 37 & $61,7 \%$ \\
2. Perempuan & 23 & $38,3 \%$ \\
\hline Usia & & \\
1. $15-45$ tahun & 18 & $30,0 \%$ \\
2. $46-75$ tahun & 42 & $70,0 \%$ \\
\hline
\end{tabular}

Distribusi pasien dengan jenis kelamin antara laki-laki dan perempuan yaitu laki-laki $61,7 \%$ dan perempuan $38,3 \%$. Insiden gagal ginjal kronik oleh karena glomerulonefritis yang dilakukan di Jepang menunjukkan bahwa laki-laki lebih banyak dibandingkan perempuan (Wakai et al,2004).

Distribusi persentase usia adalah 46-75 tahun sebesar 70,0\% dan 15-45 tahun sebesar $30,0 \%$. Jumlah pasien gagal ginjal kronik dengan usia $46-75$ tahun lebih banyak, hal ini menunjukkan bahwa usia salah satu risiko gagal ginjal kronik. Secara klinik usia pasien $46-75$ tahun mempunyai peluang atau risiko mengalami gagal ginjal kronik lebih besar dibanding usia pasien 15-45 tahun. Hal ini menunjukkan bahwa semakin bertambah usia, semakin berkurang fungsi ginjal karena disebabkan terjadinya penurunan kecepatan ekskresi glomerulus dan penurunan fungsi tubulus pada ginjal. Pada usia lanjut, fungsi ginjal dan aliran darah ke ginjal berkurang sehingga terjadi penurunan kecepatan filtrasi glomerulus sekitar 
$30 \%$ dibandingkan pada orang yang lebih muda. Fungsi tubulus juga memburuk akibat bertambahnya usia sehingga obat seperti penicilin dan litium yang secara aktif disekresi oleh tubulus ginjal tidak dapat disekresikan secara maksimal karena mengalami penurunan faal glomerulus dan tubulus (Bustami et al, 2001).

\section{Riwayat penyakit yang diderita pasien}

Riwayat penyakit dahulu yang dialami pasien merupakan salah satu variabel penting, karena gagal ginjal kronik dapat disebabkan karena obat atau penyakit kronik. Riwayat penyakit pasien pada tabel 2 .
Berdasarkan hasil penelitian diperoleh bahwa pasien gagal ginjal kronik yang menjalani hemodialisis mempunyai riwayat hepertensi terdapat 28 pasien, hal ini menunjukkan bahwa hipertensi merupakan salah satu faktor risiko gagal ginjal. Hipertensi pada pasien dengan penyakit ginjal kronis merupakan hal yang umum terjadi. Hemodialisis sebagai salah satu modalitas terapi penyakit ginjal kronis yang telah mencapai tahap akhir memicu terjadinya komplikasi hipertensi. Prosedur hemodialisis menimbulkan perubahan hemodinamika yang mengakibatkan berbagai macam komplikasi diantaranya adalah hipertensi intradialitik atau hemodialysis-induced hypertension (Horl dan Horl, 2002).

Tabel 2. Distribusi pasien berdasarkan riwayat penyakit dan keluhan pasien

\begin{tabular}{|c|l|c|c|}
\hline \multirow{2}{*}{ No. } & & \multicolumn{2}{|c|}{ Jumlah } \\
\cline { 3 - 4 } & & $\mathbf{n}$ & Riwayat penyakit \\
\hline 1 & Hipertensi & 7 & 11,7 \\
\hline 2 & Hipertensi, DM, nyeri kepala & 10 & 15 \\
\hline 3 & Hipertensi, nyeri kepala & 1 & 1,7 \\
\hline 4 & Hipertensi, hiperkolesterol, nyeri sendi \& kepala & 1 & 1,7 \\
\hline 5 & CHF, nyeri kepala & 1 & 1,7 \\
\hline 6 & Hipertensi, asam urat, nyeri sendi, nyeri kepala & 2 & 3,3 \\
\hline 7 & DM, asam urat, nyeri sendi & 2 & 3,3 \\
\hline 8 & DM, nyeri kepala & 1 & 1,7 \\
\hline 9 & DM & 3 & 5 \\
\hline 10 & Asam urat, nyeri sendi & 9 & 15 \\
\hline 11 & Nyeri sendi & 5 & 8,3 \\
\hline 12 & Nyeri sendi, nyeri kepala & 3 & 5 \\
\hline 13 & Nyeri kepala & - & - \\
\hline 14 & Demam & - & - \\
\hline 15 & Nyeri gigi & - & - \\
\hline 16 & Nyeri perut & 1 & 1,7 \\
\hline 17 & Masuk angin & 5 & 8,3 \\
\hline 18 & Stamina menurun & - & - \\
\hline 19 & Lain-lain & 60 & 100 \\
\hline & Total & & \\
\hline & & 9 & \\
\hline
\end{tabular}




\section{B. Pola Penggunaan Obat Anti- hipertensi}

Pasien yang mengalami penyakit ginjal tahap akhir umumya mendapatkan regimen antihipertensi. Antihipertensi diberikan untuk mengendalikan tekanan darah yang terjadi sebagai akibat perubahan hemodinamika. Pengendalian tekanan darah penting dilakukan karena tekanan darah merupakan faktor yang menyumbang perkembangan penyakit. Berdasarkan hasil penelitian distribusi pasien mendapatkan obat anti hipertensi, dapat dilihat pada tabel 3 .

Tabel 3. Distribusi pasien berdasarkan penggunaan jenis obat antihipertensi

\begin{tabular}{|c|c|c|}
\hline No & $\begin{array}{c}\text { Obat } \\
\text { antihipertensi }\end{array}$ & Jumlah Pasien \\
\hline & & \\
\hline 1 & Furosemida & 52 \\
\hline 2 & Captopril & 34 \\
\hline 3 & Nifedipin & 23 \\
\hline 4 & Valsartan & 12 \\
\hline 5 & Lisinopril & 7 \\
\hline 6 & Clonidin & 2 \\
\hline 7 & Amlodipin & 3 \\
\hline
\end{tabular}

Antihipertensi yang diberikan pada pasien di bangsal hemodialisis rumah sakit PKU Muhammadiyah Yogyakarta paling banyak yaitu 52 pasien. Furosemid merupakan golongan diuretik untuk mengurangi cairan yang ada didalam tubuh. Golongan penghambat enzim pengubah angiotensin (ACE inhibitor) paling umum digunakan adalah captopril sebanyak 34 pasien dan lisinopril 7 pasien. Nifedipin dan amlodipin yang merupakan golongan penghambat kanal kalsium digunakan pada 23 dan 3 pasien. Pasien yang menggunakan valsartan yang merupakan golongan angitensin renin bloker sebanyak 12 pasien. Pasien - pasien yang mendapat terapi hemodialisis umumnya mendapatkan terapi antihipertensi karena pasien-pasien tersebut mengalami episode hipertensi meskipun tidak memiliki etiologi hipertensi sebagai penyakit utama (Horl dan Horl, 2002 ; Agarwal, 2002).Rahman dan Griffin (2004) menyebutkan dalam penelitiannya bahwa obat antihipertensi yang banyak digunakan adalah nifedipin dan amlodipin yang merupakan anti- hipertensi paling umum digunakan pada pasien hipertensi yang mendapatkan hemodialisis. Prinsip terapi antihipertensi pada pasien dengan hemodialisis adalah semua jenis obat antihipertensi dapat digunakan dan efektif (dengan mempertimbangkan morbiditas pasien) kecuali diuretik yang tidak berefek jika fungsi residual berkurang atau tidak tersisa sama sekali. Terapi pilihan yang digunakan adalah angiotensin converting enzyminhibitor dan angiotensin II receptor blocker karena pertimbangan berbagai sebab yaitu sifat renoprotektif, mengatasi proteinuri dan efek yang menguntungkan pada pasien yang mengalami gangguan jantung atau gagal jantung kongestif. Namun, penyekat kanal kalsium jenis dihidropiridin seperti amlodipin paling lazim digunakan karena adanya penelitian yang mengaitkan calcium canal blocker dengan penurunan risiko mortalitas sebesar $21 \%$.

\section{Rasionalitas Penggunaan Obat Antihipertensi}

Pengobatan rasional adalah tercapainya tujuan pengobatan yang efektif, 
aman, dan ekonomis. Pada penelitian ini evaluasi rasionalitas berdasarkan tepat pasien, tepat dosis dan efek yang yang dapat terjadi berdasarkan Drug Informasi Handbook.

\section{Tepat dosis}

Pemberian obat akan memberikan efek optimal apabila dosis yang diberikan sesuai dengan kondisi pasien dan penyakit pasien. Pada pasien yang mengalami gangguan ginjal kronik dosis sangat penting dipertimbangkan karena sebagian besar obat dieliminasi pada ginjal, jika kemampuan ginjal mengekresi dan mengeliminasi sisa metabolisme maka penyesuaian dosis obat sangat penting. Penyesuaian dosis obat untuk pasien gagal ginjal kronik adalah berdasarkan data kliren kreatinin. Pada proses hemodialisa kadar obat dalam darah dapat berkurang karena mengalami dialisis, sehingga evaluasi dosis pemberian penting dilakukan. Evaluasi dosis pemberian untuk pasien hemodialisis berdasarkan kondisi pasien menggunakan literatur Drug Informasi Handbook dan Clinical Drug Data. Berdasarkan hasil penelitian evaluasi dosis pemberian, pada tabel 4 .

Tabel 4. Hasil evaluasi dosis pemberian obat anti hipertensi

\begin{tabular}{|c|l|c|c|c|}
\hline No & $\begin{array}{c}\text { Obat } \\
\text { antihiper- } \\
\text { tensi }\end{array}$ & $\begin{array}{c}\text { Tidak } \\
\text { tepat } \\
\text { dosis }\end{array}$ & $\begin{array}{c}\text { Tepat } \\
\text { dosis }\end{array}$ & Jumlah \\
\hline 1 & Furosemida & 18 & 34 & 52 \\
\hline 2 & Captopril & 23 & 11 & 34 \\
\hline 3 & Nifedipin & 3 & 20 & 23 \\
\hline 4 & Valsartan & 0 & 12 & 12 \\
\hline 5 & Lisinopril & 1 & 6 & 7 \\
\hline 6 & Clonidin & 0 & 2 & 2 \\
\hline 7 & Amlodipin & 0 & 3 & 3 \\
\hline
\end{tabular}

Tujuan pemberian furosemida pada pasien hemodialisa adalah untuk mengatur keseimbangan cairan dalam tubuh, sehingga mengurangi beban jantung memompa aliran darah. Pemberian furosemid akan meningkatkan kerja ginjal sehingga sebaiknya dihindari untuk terapi hipertensi pada pasien gagal ginjal dengan hemodilisis. Furosemid tidak terdialisis karena tidak mudah larut dalam air sehingga dosis pemberian tidak harus dinaikkan atau disesuaikan. Pasien yang melakukan hemodilisis sebaiknya mengurangi asupan cairan untuk mencegah terjadinya udem yang meningkatkan beban kerja jantung sehingga memicu terjadinya hipertensi.

Penggunaan captopril dan lisinopril pada pasien hemodialisis perlu diperhatikan karena captopril dan lisinopril mudah terdialisis karena mudah larut dalam air. Berdasarkan hasil penelitian dosis captopril $12,5 \mathrm{mg}$ tiga kali sehari, sesuai dengan dosis untuk pasien hipertensi, hal ini dapat menyebabkan efek captopril tidak optimal. Sebaiknya dosis captopril disesuaikan sehingga kadar obat dalam darah mencapai kadar maksimal dan menimbulkan efek optimal.

Nifedipin pada pasien hemodialisis dosis sesuai dengan dosis lazimnya, karena nifedipin tidak atau sedikit terdialisis, sehingga pada pasien hemodialisis kadar obat dalam darah tetap dan memberikan efek optimal seseuai dengan dosis pemberian. Namun demikian penggunaan nifedipin tetap harus dimonitoring karena efek hipotensinya cukup tinggi.

Valsartan adalah salah satu obat yang direkomendasikan untuk terapi 
hipertensi pada pasien gagal ginjal kronik karena mekanisme kerja valsartan yang memblok reseptor angiotensin. Golongan ini memiliki efek menyerupai golongan penghambat enzim pengubah angiotensin. Beberapa penelitian menunjukkan adanya keuntungan penggunaan golongan ini pada populasi pasien ginjal kronis. Golongan mengalami hemodialisis karena gagal ginjal kronik yang disebabkan riwayat hipertensi, DM, hiperuricemia, penggunaan NSAID, minuman keras dan minuman suplemen. Hasil evaluasi tepat pasien adalah obat yang diberikan tidak kontraindikasi dengan kondisi pasien atau riwayat penyakit pasien adalah pada tabel 5.

Tabel 5. Hasil evaluasi tepat pasien pemberian obat anti hipertensi

\begin{tabular}{|c|l|c|c|c|}
\hline No & Obat antihipertensi & Tidak tepat pasien & Tepat pasien & Jumlah \\
\hline 1 & Furosemida & 0 & 52 & 52 \\
\hline 2 & Captopril & 9 & 25 & 34 \\
\hline 3 & Nifedipin & 4 & 19 & 23 \\
\hline 4 & Valsartan & 0 & 12 & 12 \\
\hline 5 & Lisinopril & 3 & 4 & 7 \\
\hline 6 & Clonidin & 0 & 2 & 2 \\
\hline 7 & Amlodipin & 0 & 3 & 3 \\
\hline
\end{tabular}

ini memiliki keunggulan jika dibandingkan dengan golongan penghambat enzim pengubah angiotensin yaitu tidak menyebabkan reaksi anafilaksis dan efek samping seperti pada golongan penghambat enzim pengubah angiotensin. Golongan ini sedikit atau tidak terdialisis sehingga memungkinkan memberikan kontrol tekanan darah yang lebih baik pada pasien yang menjalani hemodialisis (Horl, M.T.,Horl,W.H. 2002)

\section{Tepat pasien}

Pemilihan obat berdasarkan kondisi pasien dapat meningkatkan efek terapi dan mencegah terjadinya efek samping yang dapat memperparah penyakit pasien. Kesalahan pemilihan obat disebabkan karena ketidaktahuan kondisi pasien dan pengetahuan obat kontraindikasi pada kondisi tertentu. Berdasarkan hasil penelitian pasien
Pada tabel 5 menunjukkan bahwa pemberian obat sudah sesuai dengan kondisi pasien atau riwayat penyakit pasien. Pada penggunaan captopril terdapat 9 pasien tidak tepat karena captopril diberikan pada pasien hemodialisa yang mempunyai riwayat DM. Berdasarkan Drug Information Handbook captopril kontraindikasi pada pasien dengan angiodema, hiperaldosteron, hipersensitiv, hiperkalemia, gangguan renal, DM dan pasien geriatri. Penggunaan nifedipin tidak tepat pasien terdapat 4 pasien karena pada penelitian ini nifedipin diberikan pada 1 pasien geriatri dan 3 pasien mempunyai riwayat CHF. Nifedipin kontraindikasi pada pasien geriatri, CHF, edema dan penyakit IBD. Berdasarkan literature furosemid kontraindikasi pada pasien gangguan gastrointestinal, pasien koma, hipersensitiv terhadap sulfonamid. Pemberian valsartan pada pasien gagal ginjal 
adalah merupakan pilihan terapi karena mekanisme valsartan yang menghambat enzim renin mengubah angiotensi. Kontraindikasi valsartan adalah hiperkalemia, hipotensi dan hiperaldosteron. Pada hasil penelitian ini valsartan diberikan pada pasien dengan kondisi yang baik dan tidak memberikan kontraindikasi. Penggunaan clonidin kontraindikasi pada pasien hipersensitiv, gangguan $\mathrm{CNS}$, gangguan gastrointestinal, sedangkan pada penelitian clonidin relative sedikit dibandingkan dengan obat lain. Amlodipin kontraindikasi pada pasien hipersensitiv, gangguan CNS, sinusitis dan CHF (Lacy,C.F, et.al.2005)

\section{Efek samping}

Efek samping obat yang di evaluasi pada penelitian ini adalah berdasarkan literatur, dan melihat kondisi pasien berdasarkan data rekam medik, namun karena penelitian retrospektif maka data efek samping tidak dapat diketahui dari kondisi pasien yang sesungguhnya atau secara lengkap.

Pasien penyakit ginjal kronis umumnya mendapatkan multi terapi antihipertensi. Efek samping akibat multi terapi tersebut dapat terjadi bagi pasien yang menjalani proses hemodialisis adalah terjadinya hipotensi, reaksi anafilaksis, retensi kalium, gangguan konduksi terutama pada pasien dengan aritmia. Efek samping yang umum dikhawatirkan terjadi adalah hipotensi intradialitik. Hipotensi intradialitik merupakan peristiwa yang umum terjadi pada pasien dengan hemodialisis dan dikaitkan sebagai komplikasi hemodialisis. Bregman etal
(2001) menyebutkan bahwa hipotensi terjadi karena berbagai sebab termasuk diantaranya adalah penggunaan antihipertensi yang mempengaruhi vasokonstriksi serta penghambatan laju jantung sehingga penggunaan antihipertensi dapat memperberat keadaan hipotensi yang ada akibat proses hemodialisis itu sendiri.

Penyebab efek samping hipotensi disebutkan oleh Bregman et al (2001) diantaranya disebabkan oleh penggunaan antihipertensi. Antihipertensi dapat menyebabkan terjadinya penurunan kemampuan tubuh dalam melakukan vasokonstriksi. Penurunan ini dapat dikaitkan dengan adanya kemungkinan terjadinya penurunan pengisian jantung atau cardiac filling. Amlodipin adalah antihipertensi golongan penghambat kanal kalsium yang titik tangkap aksinya adalah pada tonus otot polos miokardium. Konsentrasi kalsium intraseluler sangat dibutuhkan dalam kontraksi jantung sehingga dengan menghambat pemasukan kalsium melalui pengikatan pada kanal kalsium tipe $\mathrm{L}$ akan memberikan efek relaksasi atau penurunan kerja jantung. Hal tersebut menyebabkan penurunan tekanan darah dengan menurunkan luaran jantung atau cardiac output yang berakibat penurunan cardiac filling. Agarwal (2006) menyebutkan kecenderungan terjadinya amplitude fluktuasi tekanan darah yang tinggi pada pasien yang menjalani hemodialisis menandakan adanya kegagalan toleransi terhadap hemodialisis serta kegagalan jantung dalam mempertahankan luaran jantung/cardiac output. Ciri kegagalan fungsi jantung ini sebagaimana yang terjadi pada pasien dengan hipertrofi ventrikel kiri. 
Karakteristik ini yang menjadi faktor pembatas atau kewaspadaan mengenai tatalaksana hipertensi intradialitik (Horl dan Horl, 2002). Berdasarkan studi literature efek samping yang mungkin terjadi akibat penggunaan obat antihipertensi adalah, pada tabel 6 . pada pasien hemodialisis sangat perlu di lakukan monitoring karena proses dialisis sangat berpengaruh terhadap kadar obat dalam darah. Monitoring dilakukan untuk mengetahui efek terapi dan efek samping yang mungkin muncul akibat penggunaan obat. Treatment

Tabel 6. Efek samping obat antihipertensi ( Lacy,C,F, et.al, 2005)

\begin{tabular}{|c|l|l|}
\hline No & \multicolumn{1}{|c|}{ Obat antihipertensi } & \multicolumn{1}{c|}{ Efek samping obat } \\
\hline 1. & Furosemida & $\begin{array}{l}\text { Hipotensi, spasme muculus, gangguan } \\
\text { gastrointestinal, hiperdiuresis, hipokalemia }\end{array}$ \\
\hline 2. & Captopril & $\begin{array}{l}\text { Gangguan renal, kenaikan kadar serum kreatinin, } \\
\text { batuk }\end{array}$ \\
\hline 3. & Nifedipin & Batuk, gangguan CNS, gangguan gastrointestinal \\
\hline 4. & Valsartan & $\begin{array}{l}\text { Gangguan CNS, batuk, hiperkalemia, kenaikan kadar } \\
\text { kreatinin }\end{array}$ \\
\hline 5. & Lisinopril & $\begin{array}{l}\text { Gangguan gastrointestinal, meningkatkan BUN, } \\
\text { batuk,aritmia, angiodema }\end{array}$ \\
\hline 6. & Clonidin & $\begin{array}{l}\text { Gangguan GI, pernafasan, endocrine, gangguan pada } \\
\text { hepar, diuresis pada malam hari }\end{array}$ \\
\hline 7. & Amlodipin & $\begin{array}{l}\text { Gangguan GI, gangguan pernafasan dan gangguan } \\
\text { endocrine }\end{array}$ \\
\hline
\end{tabular}

Berdasarkan hasil penelitian pasien yang mengalami efek samping penggunaan obat adalah pasien mengalami mual dan muntah karena penggunaan amlodipin. Penggunaan captopril menyebabkan batuk terjadi pada beberapa pasien. Batuk yang disebabklan karena captopril tidak diberikan obat batuk karena apabila penggunaan captopril dihentikan maka batuk akan berhenti. Penggunaan furosemid dapat menyebabkan hipokalemia yang diobat dengan pemberian asupan kalium untuk mencegah terjadinya efek samping tersebut. Efek samping diketahui dengan cara memonitoring penggunaan secara berkala terhadap pasien sehingga dapat ditangani secara dini. Pasien yang menggunakan obat hipertensi akan mengalami hipotensi apabila penggunaan obatnya tidak dimonitoring. Penggunaan obat akibat efek samping tergantung akibat dari efek samping obat, berdasarkan akibatnya efek samping dibagi menjadi efek samping minor, moderate dan mayor, efek samping obat tersebut terjadi pada dosis pemberian. Berdasarkan data pada rekam medik pasien, pasien yang mengalami efek samping akibat pemakaian obat anti hipertensi pada tabel 7.

Keterbatasan dan kelemahan dari penelitian adalah metode penelitian retrospektif sehingga tidak dapat mengetahui kondisi pasien yang sebenarnya untuk mengevaluasi efek samping obat, tepat pasien dan tepat obat. Saran penelitian selanjutnya dilakukan dengan metode prospektif dan evaluasi penggunaan obat berdasarkan kondisi pasien. 


\section{KESIMPULAN}

Pola penggunaan obat anti hipertensi pada pasien gagal ginjal kronik yang menjalani hemodialisis di RSU PKU Muhammadiyah adalah captoril, furosemida, nifedipin, lisinopril, amlodipin, valsatran dan clonidin. Evaluasi rasionalitas penggunaan obat tidak tepat dosis penggunaan captopril 11 pasien dari 34 pasien dan furosemid 18 pasien dari 52 pasien, tidak tepat pasien adalah penggunaan captopril 9 pasien dari 34 pasien. Efek samping yang terjadi pada pasien akibat penggunaan furosemida adalah hipokalemia 40 pasien, batuk karena captopril adalah 13 pasien, efek samping nifedipin batuk dan gangguan gastrointestinal 11 pasien, batuk karena lisinopril 5 pasien .
Hemodialysis Patients, Clin $J$ Am Soc Nephrol ; 1:820-824.

Boehler, J., Donauer, J., Keller, F. 1999, Pharmacokinetic Principles During Continuous Renal Replacement Therapy : Drugs and Dosage, Kidney Int 56(72):S-29 S-31.

Chen, J., Gul, A., Sarnak, M.J., 2006, Management of Intradialitic Hypertension: The Ongoing Challenge, Seminars in Dialysis ;19(2):141-145.

Decker, B.S., Mueller, B.A., Sowinski, K.M. 2007, Drug Dosing Consideration in Alternative Hemodialysis, Advances in Chronic Kidney Disease; 14 (3): e17-26.

Tabel 7. Efek samping obat antihipertensi berdasarkan data rekam medik

\begin{tabular}{|c|l|l|c|c|}
\hline No & Obat antihipertensi & \multicolumn{1}{|c|}{ Efek samping obat } & $\begin{array}{c}\text { Jumlah } \\
\text { pasien }\end{array}$ & Total pasien \\
\hline 1 & Furosemida & Hipokalemia & 40 & 52 \\
\hline 2 & Captopril & Batuk & 13 & 34 \\
\hline 3 & Nifedipin & Batuk dan gastrointestinal & 11 & 23 \\
\hline 4 & Valsartan & - & - & 12 \\
\hline 5 & Lisinopril & Batuk & 5 & 7 \\
\hline 6 & Clonidin & - & - & 2 \\
\hline 7 & Amlodipin & - & - & 3 \\
\hline
\end{tabular}

\section{DAFTAR PUSTAKA}

Agarwal, R, 1999, Supervised Atenolol Therapy in The Management of Hemodialysis Hypertension, Kidney Int., ;55:1528-35.

Bishu, K, 2006, Appropriatness of Antihypertensive Drug Therapy in
Horl, M.T., Horl,W.H. 2002, Hemodialysis-Associated Hypertension: Pathophysiology and Therapy, Am $J$ Kidney Dis,2002; 39(2):227-44.

Johnson, C.A., 2008, 2008 Dialysis of Drugs, CKD Insight, LLC Joy, M.,, A.,Franceshini, N., 2008, Chronic Kidney Disease: 
Progression-Modifying Therapies dalam Dipiro, J.T. et al (Eds.) Pharmacotherapy A

Pathophysiologic Approach 7th Ed. eBook version McGraw-Hill, New York, hal. 745 - 765.

Keller, F., Bohler, J., Czock, D., Zellner, D., Mertz, A.K.H. 1999, Individualized Drug Dosage in Patients Treated with Continuous Hemofiltration, Kidney Int;56(72):S-29 - S-31.

Koomans, H.A., Blankestijn, P.J., Joles, J.A. 2004, Sympathetic Hyperactivity in Chronic Renal failure: A Wake-up Call, J Am Soc Nephrol;15:524-537.

National Kidney Foundation, 2005, K/DOQI Clinical Practice Guidelines for Cardiovascular Disease in Dialysis Patients.

Levey, A.S., Coresh, J., Balk, E., Kaustz, A.T., Levin. A, 2003. National Kidney Foundation practice guidelines for chronic kidney disease: evaluasi, klasifikasi and stratification; Ann Intern Med; 137-147.

Lacy,C.F, Lexi-comp, Lora L Amstrong, 2005, Drug Information Handbook, Edisi 11, America Pharmaceutical Association.

Price, wilson. (2006). Pathofisiologi Konsep Klinik Proses-Proses Penyakit. EGC. Jakarta.

Quan, D.J., Aweeka, F.T., 2005, Dosing of Drugs in Renal Failure, in Applied Therapeutics : The Clinical Use of Drugs 8th Ed. Koda-Kimble et al. (Eds.)
Lippincott Williams \& Wilkins, New York , p.34(1-26).

Quick, J.D., Rankin, J.R, Lanig, R.O., O'Connor, R.W., Hogerzeil, H.V., Dukes, M.N.G., Garnet, A., 1997, Managing Drug Suplay, 423-424, Kumarian Press Inc, Connecticut, USA.

Rahman, M., Griffin, V., 2004, Patterns of Antihypertensive Medication Use in Hemodialysis Patients, $A m$ $J$ Health-Syst Pharm, 2004;61(14):1473-78.

Salem, M. 1999, Hypertension in The Hemodialysis population: How little do we know, Saudi J Kidney Dis Transplant; 10 (3): 283-285.

Saracho, R., Martin-Malo, A., Martinez, I., Aljama, P., Montenegro, J. 1998 ,Evaluation of Losartan in hemodialysis (ELHE) Study, Kidney Int.,,;54(68):S-125-S129.

Shargel, L., Yu,H A.B.C., 1985, Biofarmasetika dan Farmakokinetika Terapan, Edisi 2, Universitas Airlangga, urabaya, hal. 417-420.

Stevens, L.A., Coresh, J., Greene, T., Levey, A.S., Assessing Kidney Stevens, L.A., Coresh, J., Greene, T., Levey, A.S 2006., Assessing Kidney Function.Measured and Estimated Glomerular Filtration Rate, NEngl JMed,; 354:2473-83.

Saint-Remy, A., Krzesinski, JM, 2005., Optimal Blood Pressure Level and Best Measurement procedure in Hemodialysis Patients, Vascular Health and Risk Management, I(3) 235-44. 
Schonder, K.S., 2008, Chronic and End-Stage Renal Disease in Chisholm-Burns et al (Eds.) Pharmacotherapy : Principles \& Practices, McGraw-Hill, New York, hal. 373-402.

Zoccali, C., Dunea, G., 2001, Hypertension in Handbook of
Dialysis oleh Daugirdas (Ed), McGraw-Hill, New York, hal.467 - 475 6th Ed. McGraw-Hill, New York. Hal $851-870$. 